\title{
Vulvar Cancer Pathologic Distant Metastasis TNM Finding v7
}

National Cancer Institute

\section{Source}

National Cancer Institute. Vulvar Cancer Pathologic Distant Metastasis TNM Finding v7. NCI Thesaurus. Code C89439.

A pathologic finding about one or more characteristics of vulvar cancer, following the rules of the TNM AJCC V7 classification system as they pertain to distant metastases. There is no pathologic M0 for vulvar cancer. 